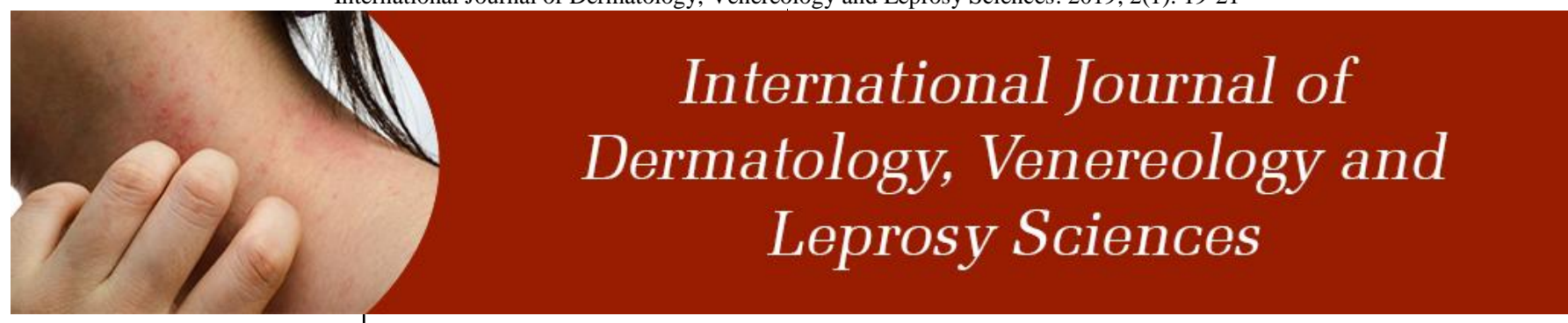

E-ISSN: 2664-942X P-ISSN: 2664-9411 www.dermatologypaper.com/ Derma 2019; 2(1): 19-21 Received: 16-11-2018 Accepted: 19-12-2018

\section{Krishna Thapa}

Department of Dermatology, Universal College of Medical Sciences, Nepal
Corresponding Author: Krishna Thapa

Department of Dermatology, Universal College of Medical Sciences, Nepal

\section{Determine of S100A8 level in patients of chronic spontaneous uritcaria}

\section{Krishna Thapa}

DOI: https://doi.org/10.33545/26649411.2019.v2.i1a.21

\begin{abstract}
Introduction: Chronic spontaneous uritcaria (CSU) is characterized by the spontaneous appearance of transient itchy wheals, angioedema or both, for at least 6 weeks. The present study was conducted to determine level of S100A8 in patients of chronic spontaneous uritcaria.

Materials \& Methods: The present study was conducted on 82 cases (Group I) of chronic spontaneous uritcaria of both genders. Equal number of healthy subjects (Group II) was also taken. CSU was diagnosed according to the EAACI/GA2 LEN/ EDF/WAO guidelines. Plasma levels of S100A8 were assessed using human enzyme linked immunosorbent assay (ELISA) kit.

Results: There were 34 male and 48 female in group I and 42 males and 40 female in group II. Mean age in group I was 27.1 years and in group II was 29.2 years. Basophil count was $0.21 \%$ in group I and $0.45 \%$ in group II. Eosinophil count was $1.62 \%$ in group I and $2.15 \%$ in group II. The mean S100A8 level in group I was $2415.6 \mathrm{pg} / \mathrm{ml}$ and in group II was $1380.9 \mathrm{pg} / \mathrm{ml}$.

Conclusion: Authors found that Plasma S100A8 level was higher in CSU patients. It may serve as biomarkers of CSU.
\end{abstract}

Keywords: Basophil, Chronic spontaneous uritcaria, S100A8

\section{Introduction}

Chronic spontaneous uritcaria (CSU) is characterized by the spontaneous appearance of transient itchy wheals, angioedema or both, for at least 6 weeks. While it affects $0.5 \%-1 \%$ of the population, it not only has negative visual impact on patients, but also decreases the quality of life ${ }^{[1]}$. CSU is an inflammatory disease, probably caused by an interactive combination of immune, genetic, and environmental factors, including infections. Various changes in levels of immune-inflammatory, coagulation/fibrinolytic, hormonal, and metabolic markers have been reported in CSU patients ${ }^{[2]}$.

Urticaria presents with wheals (hives), angioedema, or both, and has a lifetime prevalence of about $9 \%$. The appearance of pruritic, erythematous dermal swellings that blanch with pressure, indicating the presence of vasodilation and superficial dermal edema, is characteristic of wheals ${ }^{[3]}$. Angioedema is caused by similar pathologic alterations that occur in the reticular dermis and subcutaneous tissue, with poorly defined swelling and burning. One-third of patients present with both hives and angioedema, 30\% to $40 \%$ present with isolated hives, and $10 \%$ to $20 \%$ with isolated angioedema ${ }^{[4]}$.

S100 family consists of a serial of EF-hand calcium $(\mathrm{Ca} 2+)$-binding proteins, with more than 20 distinguished proteins. It is reported that S100A8, S100A9, and S100A12 play important roles in the pathogenesis of immunological disorders in the human body. They are involved in the development of autoimmune-associated diseases, such as psoriasis, rheumatoid arthritis, and systemic lupus erythematosus ${ }^{[5]}$. The present study was conducted to determine level of S100A8 in patients of chronic spontaneous uritcaria.

\section{Materials \& Methods}

The present study was conducted in the department of Dermatology. It comprised of 82 cases (Group I) of chronic spontaneous uritcaria of both genders. Equal number of healthy subjects (Group II) was also taken. All were informed regarding the study and written consent was obtained. Ethical clearance was taken before starting the study.

General information such as name, age, etc. was recorded. In all cases, the clinical and 
dermoscopic characteristics were recorded. CSU was diagnosed according to the EAACI/GA2 LEN/ EDF/WAO guidelines. Urticaria Activity Score (UAS) was used to assess the activity of urticaria, including the wheal numbers and pruritus. Plasma levels of S100A8 were assessed using human enzyme linked immunosorbent assay (ELISA) kit. Results thus obtained were subjected to statistical analysis. $P$ value less than 0.05 was considered significant.

\section{Results}

Table I: Assessment of parameters

\begin{tabular}{|c|c|c|}
\hline Variables & Group I (Cases) & Group II (Control) \\
\hline Male & 34 & 42 \\
\hline Female & 48 & 40 \\
\hline Mean age (Years) & 27.1 & 29.2 \\
\hline Basophil \% & 0.21 & 0.45 \\
\hline Eosinophil \% & 1.62 & 2.15 \\
\hline
\end{tabular}

Table I shows that there were 34 male and 48 female in group I and 42 males and 40 female in group II. Mean age in group I was 27.1 years and in group II was 29.2 years. Basophil count was $0.21 \%$ in group I and $0.45 \%$ in group II. Eosinophil count was $1.62 \%$ in group I and $2.15 \%$ in group II.

Table II: Assessment of S100A8 in both groups

\begin{tabular}{|c|c|c|}
\hline Variables & Mean $(\mathbf{p g} / \mathbf{m l})$ & P value \\
\hline Group I & 2415.6 & \multirow{2}{*}{0.05} \\
\hline Group II & 1380.9 & \\
\hline
\end{tabular}

Table II, graph I shows that mean S100A8 level in group I was $2415.6 \mathrm{pg} / \mathrm{ml}$ and in group II was $1380.9 \mathrm{pg} / \mathrm{ml}$.

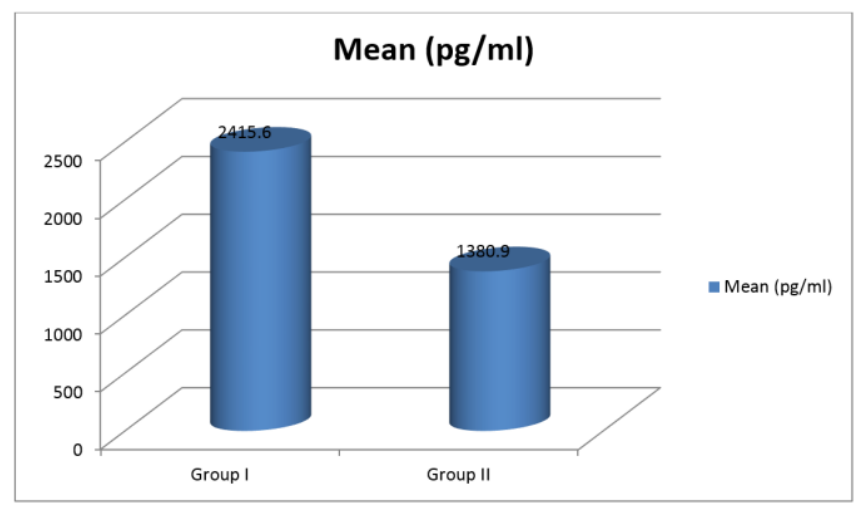

Graph I: Assessment of S100A8 in both groups

\section{Discussion}

Urticaria may be classified into acute or chronic. Acute urticaria (AU) is defined by the occurrence of spontaneous wheals or angioedema for $<6$ weeks. In acute cases, it is important to exclude anaphylaxis in the presence of respiratory, gastrointestinal, or neurologic symptoms or hemodynamic instability [6]. Eliciting factors have been found in $<50 \%$ of cases, with upper respiratory infections being the most common trigger $(40 \%)$, followed by drug reactions $(9.2 \%)$ and suspected food intolerance $(0.9 \%)$. Among infectious agents, upper respiratory tract agents, Mycoplasma pneumonia, and parasitic infections have been commonly reported in children, while viral hepatitis and infectious mononucleosis are important culprits in adults ${ }^{[7]}$. The present study was conducted to determine level of
S100A8 in patients of chronic spontaneous uritcaria.

In this study, there were 34 male and 48 female in group I and 42 males and 40 female in group II. Mean age in group I was 27.1 years and in group II was 29.2 years. Basophil count was $0.21 \%$ in group I and $0.45 \%$ in group II. Eosinophil count was $1.62 \%$ in group I and $2.15 \%$ in group II.

Zhou et al. ${ }^{[8]}$ assessed the levels of plasma S100A8, S100A9, and S100A12 were measured in 51 CSU patients and 20 healthy controls using enzyme linked immunosorbent assay kits. The values in the patient group and that of the healthy controls were statistically compared. The plasma levels of S100A8, S100A9, and S100A12 were significantly higher in CSU patients than those in controls. Interestingly, the level of S100A12 was significantly correlated with S100A8 and S100A9 in CSU patients $(P<$ 0.05 and $P<0.001$, respectively). In addition, S100A8, S100A9, and S100A12 were all significantly inversely correlated with blood basophil percentage.

We observed that mean S100A8 level in group I was 2415.6 $\mathrm{pg} / \mathrm{ml}$ and in group II was $1380.9 \mathrm{pg} / \mathrm{ml}$. About one-third to one-half of patients with CSU show a positive response against their own serum (positive autologous serum skin test [ASST]). IgG antibodies to the high-affinity $\operatorname{IgE}$ receptor FceRIa, or less commonly IgG antibodies to IgE, have been documented. There seems to be an increased risk for thyroid disorders (hypothyroidism more often than hyperthyroidism), diabetes mellitus type I, systemic lupus erythematous, and rheumatoid arthritis in patients with $\mathrm{CaU}$. Although these autoantibodies are of academic interest, as some studies report a more intense refractory course, their clinical relevance remains unclear ${ }^{[9]}$.

The exact pathogenic role of S100A8, S100A9, and S100A12 in the development of CSU is still unknown. Three S100 proteins are involved in the pathogenesis of CSU in several ways. Firstly, these three S100 proteins bind to and activate responses by two widely expressed but divergent receptors, namely, toll-like receptor 4 (TLR4) and the receptor for advanced glycation end-products (RAGE). The engagement of these two receptors by $\mathrm{S} 100$ proteins is linked to an array of signaling pathways, notably NF- $\kappa \mathrm{B}$ and mitogen-activated protein kinases; the induction of $\mathrm{p} 38$ signaling was known to trigger the release of proinflammatory cytokines including interleukin (IL)-6, tumor necrosis factor (TNF)- $\alpha$, and IL-1 $\beta$ through the action of NF- $\kappa \mathrm{B}^{[10]}$.

\section{Conclusion}

Authors found that Plasma S100A8 level was higher in CSU patients. It may serve as biomarkers of CSU.

\section{References}

1. Zuberbier T, Balke M, Worm M, Edenharter G, Maurer M. Epidemiology of urticaria: A representative crosssectional population survey. Clin Exp Dermatol. 2010; 35:869-873.

2. Sanchez J, Amaya E, Acevedo A, Celis A, Caraballo D, Cardona R. Prevalence of inducible urticaria in patients with chronic spontaneous urticaria: associated risk factors. J Allergy Clin Immunol Pract. 2017; 5:464-470.

3. Zuberbier T, Maurer M. Urticaria: current opinions about etiology, diagnosis and therapy. Acta Derm Venereol. 2007; 87: 196-205.

4. Champion RH, Roberts SO, Carpenter RG, Roger JH. 
Urticaria and angio-oedema. A review of 554 patients. Br J Dermatol. 1969; 81:588-597.

5. Wedi B, Raap U, Wieczorek D, Kapp A. Urticaria and infections. Allergy Asthma Clin Immunol 2009; 5:10.

6. Zuberbier T, Ifflander J, Semmler C, Henz BM. Acute urticaria: clinical aspects and therapeutic responsiveness. Acta Derm Venereol. 1996; 76:295297.

7. Wedi B, Raap U, Wieczorek D, Kapp A. Urticaria and infections. Allergy Asthma Clin Immunol. 2009; 5:10.

8. Zhou $\mathrm{Q}^{-} \mathrm{Y}$, Lin W, Zhu $\mathrm{X}^{-} \mathrm{X}, \mathrm{Xu} \mathrm{S}-\mathrm{L}$, Ying $\mathrm{M}^{-} \mathrm{X}$, Shi L, et al. Increased plasma levels of S100A8, S100A9, and S100A12 in chronic spontaneous urticaria. Indian J Dermatol 2019; 64:441-6.

9. Williams KW, Sharma HP. Anaphylaxis and urticaria. Immunol Allergy Clin North Am. 2015; 35:199-219.

10. Mathias SD, Crosby RD, Zazzali JL, Maurer M, Saini SS. Evaluating the minimally important difference of the urticaria activity score and other measures of disease activity in patients with chronic idiopathic urticaria. Ann Allergy Asthma Immunol 2012; 108:204. 